\title{
Metabolic Studies of the Growth Regulator, Maleic Hydrazide*
}

by

Matthias Haas, Peter Schröder, Dieter Komoßa and Heinrich Sandermann, Jr

GSF Forschungszentrum für Umwelt und Gesundheit $\mathrm{GmbH}$, Institut für Biochemische Pflanzenpathologie, Ingolstädter Landstraße 1, D.85758 Oberschleißheim, Germany

and

Robert G. May

ghb Gebrüder Huber Bodenrecycling GmbH, Tannenwaldstr. 2, D-81375 Munich, Germany

\section{SUMMARY}

The metabolism of the plant growth regulator maleic hydrazide $(\mathrm{MH})$ has been studied in sterile cell suspension cultures of tobacco, soybean, maize and wheat under standardized conditions. Maleic hydrazide was converted to its $O-\beta$-D- glucoside in yields between $9.0 \%$ (tobacco) $15.0 \%$ (soybean), $5.1 \%$ (maize) and $2.2 \%$ (wheat) respectively. This glucoside was completely cleaved under simulated conditions $\left(\mathrm{pH} 1,37^{\circ} \mathrm{C}, 24 \mathrm{~h}\right)$ of a ruminant stomach. From these results it is concluded that $\mathrm{MH}-\mathrm{O}-\beta$ - $\mathrm{D}$-glucoside (MHG) belongs to a small group of acid-labile pesticide conjugates (11). The participation of a glucosyltransferase (GT) (EC 2.4.1-) in this conjugation reaction of $\mathrm{MH}$ was demonstrated in vitro for the first time. In addition, up to $18 \%$ of the applied maleic hydrazide became associated with nonextractable residues (NER) in soybean, whereas in tobacco only $0.2 \%$ could be detected in this fraction. The residue from soybean cells was solubilized only to a low degree (about $3 \%$ ) under simulated stomach conditions, but up to $20 \%$ by the white rot fungus Phanerochaete chrysosporium.

*Received: 13th June 1997 - accepted 4th November 1997

\section{ZUSAMMENFASSUNG}

Der Metabolismus des Wachstumsregulators Maleinsäurehydrazid $(\mathrm{MH})$ wurde in sterilen, pflanzlichen Suspensionszellkulturen von Tabak, Soja, Mais und Weizen unter standardisierten Bedingungen untersucht. Maleinsäurehydrazid wurde in den Zellkulturen in Anteilen von 9,0 \% (Tabak), 15,0 \% (Soja), 5,1 \% (Mais) und 2,2\% (Weizen) zu einem $O-\beta$-D-Glucosid konjugiert. Dieses Glucosid wurde unter den simulierten Bedingungen $\left(\mathrm{pH} 1,37^{\circ} \mathrm{C}, 24 \mathrm{~h}\right)$ eines Wiederkäuermagens vollständig gespalten. Aufgrund dieser Ergebnisse wurde dieses $\mathrm{MH}$ $O-\beta$-D.Glucosid (MHG) der Gruppe der selten beschriebenen, säurelabilen Pestizidkonjugate zugeordnet (11). Zum ersten Mal konnte die Beteiligung einer Glucosyltransferase (GT) (EC 2.4.1-) an dieser Konjugationsreaktion des $\mathrm{MH}$ durch entsprechende Enzymtests in vitro gezeigt werden. Zusätzlich waren bis zu $18 \%$ des eingesetzten Maleinsäurehydrazids in Soja als nichtextrahierbarer Rückstand (NER) assoziiert, während dieser Anteil in Tabak nur 0,2 \% betrug. Die NER aus Soja waren unter den Bedingungen des simulierten Magens nur in Anteilen von um die $3 \%$ wieder freisetzbar, während der Weißfäulepilz Phanerochaete chrysosporium bis zu $20 \%$ mobilisieren konnte. 


\section{RESUME}

Le métabolisme du régulateur de croissance acide maléique hydracide $(\mathrm{MH})$ a été étudié à partir de cultures cellulaires de tabac, soja, maïs et blé en conditions standard. $L$ 'acide maléique hydracide a été converti en son $O-\beta-D-$ glucoside selon des taux de $9,0 \%$ (tabac), $15,0 \%$ (soja), $5,1 \%$ (mais) et $2,2 \%$ (blé). Le clivage complet de ce glucoside a été réalisé en simulant les conditions $(\mathrm{pH} 1$, $37^{\circ} \mathrm{C}, 24 \mathrm{~h}$ ) d'un estomac de ruminant. Ces résultats indiquent que le $\mathrm{MH}-\mathrm{O}-\beta$-D-glucoside (MHG)appartient à un petit groupe de conjugués pesticides acide-labiles (11). L'intervention d'une glucosyltransférase (GT) (EC 2.4.1-) dans cette réaction de conjugaison de $\mathrm{MH}$ a été démontrée in vitro pour la première fois. De plus, jusqu' à $18 \%$ de l'acide maléique hydracide apporté se sont associés aux résidus non extractibles (NER) chez le soja, alors que chez le tabac, seulement $0,2 \%$ n'a pu être détecté dans cette fraction. Le résidu des cellules de soja a été solubilisé à un faible niveau seulement (environ $3 \%$ ) dans les circonstances expérimentales simulant les conditions de l'estomac, mais jusqu'à $20 \%$ par la moisissure Phanerochaete chrysosporium.

\section{INTRODUCTION}

Maleic hydrazide (6-Hydroxy-3- $\left(2 H^{-}\right)$-pyridazinone) is a growth regulator used mainly to control lateral bud growth (suckers) on freshly topped tobacco plants (1). It is believed to inhibit cell division without affecting cell elongation, thereby preventing growth of new suckers, while allowing mature leaves to grow normally. Previously, it has also been applied as a herbicide on beets, potatoes and onions. There have been many reports concerning the toxicity of $\mathrm{MH}$ due to the uptake through skin contact, smoking and via the food chain (reviewed by MEYER et al., (2)).

Contradictory results exist about the metabolic fate and the environmental hazardousness of $\mathrm{MH}$. One study of $\mathrm{MH}$ in tobacco plants revealed an $85 \%$ reduction of the parent compound within three weeks yielding both nonextractable as well as extractable metabolites. The main fraction of the nonextractable part was incorporated into lignin, while the principal extractable component was found to be a $\beta$-D-glucoside (3). Between $20-60 \%$ of free $\mathrm{MH}$ could be released from the nonextractable residue either by treatment with acid or base, or by thermolysis in 2-amino ethanol $(3,4)$. Based on these and other results, both free $\mathrm{MH}$ and bound metabolic products were proposed to be potentially hazardous in plant food materials (4). These results are contradictory to statements that $\mathrm{MH}$ becomes fixed in plants and remains unmetabolized (1).

In view of the unusually simple reported whole-plant
MH metabolism, it has now been examined whether the MH metabolite pattern can be reproduced in a standardized plant cell culture test previously described (5). The participation of a GT (EC 2.4.1-) in the metabolism of $\mathrm{MH}$ was demonstrated in vitro after the extraction of the enzyme from cell cultures and whole plants. In addition, the isolated $\beta$-D-glucoside and the nonextractable residue formed from $\mathrm{MH}$ were exposed to simulated stomach $\mathrm{pH}$ conditions and to digestion by the white rot fungus Phanerochaete chrysosporium as first tests of bioavailability.

\section{MATERIALS AND METHODS}

\section{Chemicals}

All chemicals were of analytical grade and, unless otherwise mentioned, were used without previous purification. Deionized water was obtained from a Seral (Munich, FRG) ion exchange system. Maleic hydrazide was from Riedel-de Haen (Seelze, FRG). MH-O- $\beta$-D- glucoside was synthesized according to NEwSOME (6).

\section{Radiochemicals}

[2,3- ${ }^{14} \mathrm{C}$-Maleic hydrazide (specific activity $9.3 \mathrm{MBq} / \mathrm{mg}$; radiochemical purity $>99 \%$ as determined by HPLC) was obtained from Pathfinder (St. Louis, USA).

[UL-ring $\cdot{ }^{1+} \mathrm{C}$-toluene (Amersham, Braunschweig, FRG; specific activity $12,46 \mathrm{kBq} / \mathrm{ml}$ ) was used to an internal ISC (Liquid Scintillation Counter) standard. $\left[1-{ }^{14} \mathrm{C}\right]$ hexadecane (Amersham, Braunschweig, FRG; specific activity $1,46 \mathrm{kBq} / \mathrm{ml}$ ) was used to calibrate the biological oxidizer.

\section{Plant cell cultures}

Cell suspension cultures of soybean (Glycine max L. Merr. cv. Mandarin), wheat (Triticum aestivum L. cv. Heines Koga II) and maize (Zea mays L. cv. Black Mexican Sweet) were grown as previously described (5). Tobacco cell cultures (Nicotiana tabacum L. cv. Bel B) were grown on a modified medium according to GAMBORG and coworkers containing $2 \mathrm{mg} / \mathrm{l}$ 2,4-D (2,4dichlorophenoxyacetic acid) and 0,2 mg/l Kinetin (7).

White-rot fungus, medium composition and culture conditions

The white rot fungus Phanerochaete chrysosporium (Burdsall, ATCC 24725) was a kind gift from Prof. I. 
FIECHTER (ETH, Zurich) and was used for all incubations. Storage, subculturing of basidiospores, preparation of the inoculant and measurement of spore density at $650 \mathrm{~nm}$ were conducted as previously reported $(8,9)$. Incubation flasks were aerated for $30 \mathrm{~min}$ with moist, sterile $(0.2 \mu \mathrm{m}$ filter, SM 16534 Sartorius, Göttingen, FRG) air at day 0 , and thereafter with $100 \%$ oxygen every three days. Low-nitrogen (low-N) medium as well as inoculum were prepared as described $(8,9)$. At least $5 \times 10^{6}$ spores, obtained from malt-agar slant cultures of P. chrysosporium was used per $100 \mathrm{ml}$ of medium per flask. Typically, three culture flasks with fungus and 1-2 sterile control flasks were employed per treatment group. Flasks were shaken at $125 \mathrm{rpm}$ at $39^{\circ} \mathrm{C}$ in the dark.

\section{Determination of radioactivity}

The determination of radioactivity in solution, in HPLC eluates, in ${ }^{14} \mathrm{CO}_{2}$, and in the bound residues was carried out as described $(5,9)$. Aqueous solutions and fungal medium (maximum volume $=2 \mathrm{ml}$ ) were measured in $10 \mathrm{ml}$ Hydroluma (J. T. Baker, Groß-Gerau, FRG). Organic solutions, kerosene and $\mathrm{CO}_{2}$ trapping fluids (maximum volume $2 \mathrm{ml}$ ) were measured in a $10 \mathrm{ml}$ cocktail and standardized as previously described by KOMOßA and co-workers (5).

\section{Sample combustion to carbon dioxide and water}

Freeze dried samples were oxidized in a 2 channel $\left(\mathrm{H},{ }^{14} \mathrm{C}\right)$ biological oxidizer (Zinsser, Frankfurt, FRG) as previously described (5). Memory effects and background radiation were controlled by burning an empty sample spoon after every 4 samples. Combustion efficiency and linearity were standardized with $\left[1-{ }^{14} \mathrm{C}\right]$-hexadecane (Amersham, Braunschweig, FRG).

\section{HPLC conditions (cell cultures and enzyme assays)}

Aliquots $(50 \mu 1)$ of concentrated extracts of the cell culture cells or of the enzyme assays were analysed on a Merck (Darmstadt, FRG) HPLC system consisting of a L-6200 intelligent pump, a UV-visible detector (Applied Biosystems, Weiterstadt, FRG) a Ramona RSM (Raytest, Straubenhardt, FRG) radiodetector and a Gilson 234 autoinjector (Gilson, Langenfeld, FRG). Separation of $\mathrm{MH}$ and $\mathrm{MHG}$ was performed by modification of a published method by NEwSOME (6), using a Spherisorb SAX column ( $250 \times 4.6 \mathrm{~mm}, 5 \mu \mathrm{M}$; Bischoff, Leonberg, FRG) and isocratic elution with $0,1 \mathrm{M}$ acetic acid (adjusted to $\mathrm{pH} 4.8$ with tetramethyl-ammonium hydroxide) at a flow rate of $0.75 \mathrm{ml} / \mathrm{min}$.

\section{HPLC conditions (fungal incubations)}

Sample extracts were measured on a Waters-Millipore (Eschborn, FRG) HPLC system comprised of two 510 pumps, a 996 PDA detector, a 470 fluorescence detector, a Ramona (Raytest, Straubenhardt, FRG) radiodetector and $\mathrm{a} 717$ plus autosampler. The analytical column was a VYDAC 210 TP $54(\mathrm{Sep} / \mathrm{a} / \mathrm{ra} /$ tions Group, Hesperia, USA) operated under the following conditions:

Eluent $A$, acetonitrile;

Eluent $B$, water acidified with $1 \mathrm{ml} \mathrm{H}_{3} \mathrm{PO}_{4} / 1$.

Gradient: 0-3 min, 0\% A; 3-28 min, linear to $100 \% \mathrm{~A}$, at a flow rate of $1.5 \mathrm{ml} / \mathrm{min}$.

\section{Metabolism in cell cultures}

Incubation and extraction of the plant cell cultures were performed according to slightly modified literature procedures $(5,10)$. Filter-sterilized $\left[2,3{ }^{14} \mathrm{C}\right] \mathrm{MH}(37 \mathrm{kBq}$; $1 \mathrm{ppm}$, corresponding to $8,9 \mu \mathrm{m})$ was added in $40 \mu \mathrm{l}$

Table 1.

Maleic hydrazide metabolism in plant cell suspension cultures. The distribution of applied radioactivity (\%) after $48 \mathrm{~h}$ is shown for culture medium, cell extract (in parenthesis percentage of detected $O-\beta$-D-glucoside) and nonextractable residues (NER). Values are given as average of 4 replicates \pm standard deviations.

Radioactivity (\% of applied radioactivity)

\begin{tabular}{lcc|cc}
\hline \multicolumn{1}{c}{ Cell culture } & $\begin{array}{c}\text { Growth } \\
\text { medium }\end{array}$ & Cell extract $(\% \mathrm{MHG})$ & $\begin{array}{c}\text { Non extractable } \\
\text { residue (NER) }\end{array}$ & Recovery \\
\hline Soybean & $42.1 \pm 1.8$ & & 18.3 & $89.9 \pm 1.7$ \\
Wheat & $61.1 \pm 5.2$ & $39.1 \pm 4.3(2.2)$ & 2.6 & $102.8 \pm 5.4$ \\
Maize & $44.9 \pm 3.2$ & $29.5 \pm 2.3(15.0)$ & 0.2 & $105.2 \pm 5.2$ \\
Tobacco & $68.8 \pm 1.9$ & $24.6 \pm 1.0(9.0)$ & 0.2 & $93.6 \pm 1.4$ \\
\hline
\end{tabular}


methanol to the cell cultures (growing in $40 \mathrm{ml}$ medium) on the fifth day of growth for tobacco and soybean, and at the 12th day for maize and wheat. After an incubation period of generally $48 \mathrm{~h}$, the medium was separated from the cells by vacuum filtration. The extraction procedure for the cells leading to methanol extracts containing "soluble metabolites" and the remaining "nonextractable residue fraction" is described in detail (11).

\section{Clean up procedure for purifying $M H G$}

MHG was extracted from the methanolic fraction from the cell cultured cells on activated carbon disks (SPEDisks; Empore ${ }^{\mathrm{TM}}$, 3M, St. Paul, USA) using a modified clean up procedure according to HAAS (7).

\section{Mild acid hydrolysis}

Mild acid hydrolysis with aliquots of the bound residue fractions and MHG were performed as previously described (11).

\section{Quantification of mineralization in fungal incubations}

The pressure exit of the fungal culture flask was connected to an impinger trap containing $20 \mathrm{ml}$ kerosene (Fluka, Neu-Ulm, FRG), followed by another trap containing $20 \mathrm{ml}$ of 2-methoxyethanol/ethanolamine 2:1 (v/v) (Fluka, Neu Ulm, FRG). Immediately following oxygen flushing, as explained above in culture conditions, 1 or $2 \mathrm{ml}$ liquid medium was withdrawn and used for the analysis of metabolites by HPLC as well as for the determinations of ligninase activity and of radioactivity. After removal of medium, the flasks were again sealed and reoxygenated for $20 \mathrm{~min}$. Samples of 1 or $2 \mathrm{ml}$ from the kerosene and ${ }^{14} \mathrm{CO}_{2}$-traps were mixed with scintillation fluid.

\section{Determination of glucosyltransferase activity}

The extraction of the protein fraction showing GT activity (EC 2.4.1-) with $\mathrm{MH}$ was achieved by stepwise precipitation with ammonium sulphate $(0-40 ; 40-75 \%)$ and desalting on Sephadex G25 material (PD columns, Pharmacia, FRG). Enzyme assays were performed by pipetting $50 \mu \mathrm{l}$ buffer (Tris/ $\mathrm{HCl} \mathrm{pH} \mathrm{7.5),} 20 \mu \mathrm{l}$ uridine diphosphate glucose (UDPG) $(20 \mathrm{mM}), 20 \mu !{ }^{1+} \mathrm{C}-\mathrm{MH}$ $(22,4 \mathrm{mM})$ and $10 \mu \mathrm{l}$ Salicin $(25 \mathrm{mM}$ for $\beta$-glucosidase protection) in a reaction tube. The enzymatic reaction was started by adding $100 \mu 1$ protein extract and was incubated for $40 \mathrm{~min}$ at $37^{\circ} \mathrm{C}$. The reaction was stopped with $100 \mu l$ of dichloromethane. Specific activities were calculated based on transformation rates according to HPLC analysis (7).

\section{Determination of Ligninase Activity}

Total ligninase (EC 1.11.17; (12,13)) activity was measured spectrophotometrically by following the rate of veratroyl aldehyde production at $310 \mathrm{~nm}$ and $23^{\circ} \mathrm{C}$ in plastic cuvettes (light path $1 \mathrm{~cm}$ ) $30 \mathrm{sec}$ after mixing the solutions in the following order: $500 \mu \mathrm{l} 1 \mathrm{M}$ sodium phosphate buffer ( $\mathrm{pH} 3.2), 20 \mu \mathrm{l} 100 \mathrm{mM}$ veratroyl alcohol, $100 \mathrm{ml}$ fungal culture medium, $860 \mathrm{ml}$ water, and 20 ml $27 \mathrm{mM} \mathrm{H} \mathrm{H}_{2} \mathrm{O}_{2}$. One enzyme unit was defined as formation of $1.0 \mathrm{mM}$ veratroyl aldehyde from veratroyl alcohol per min.

\section{Determination of protein concentration}

The determination of total protein was performed using the Biorad protein assay kit (Biorad, Munich, FRG) according to BRADFORD (14) using bovine serum albu$\min$ as the standard.

\section{Mass Spectrometry and Solid Probe Inlet}

Aliquots of the isolated MHG and a synthesized standard were analysed on a Finnigan SSQ 7000 single stage mass spectrometer (MS) equipped with a solid probe inlet (7). In all MS experiments, the mass range was $50-500 \mathrm{~m} / \mathrm{z}$, at an increasing scan rate (UP) of 0.50 cycles/sec. The manifold temperature was $70^{\circ} \mathrm{C}$, the electron multiplier was set at 1200 and the peak width set to 1 . In the electron impact mode, the electron current was $70 \mathrm{eV}$ at an ion source temperature of $180^{\circ} \mathrm{C}$. For chemical ionization experiments (CI), methane (Linde; Höllriegelskreuth, FRG) was the reactant gas at a manifold pressure of ca $900 \mathrm{mT}$ Torr. The electron current was $120 \mathrm{eV}$ at an ion source temperature of $130^{\circ} \mathrm{C}$. In all cases, the following solid probe temperature program was used: $50^{\circ} \mathrm{C}$ to $800^{\circ} \mathrm{C}$ at $200^{\circ} \mathrm{C} \mathrm{min}^{-1}$.

\section{RESULTS}

\section{Metabolism in cell cultures}

A standardized test for plant suspension cultures $(5,10)$ was used to determine the distribution of radioactivity among the different fractions (medium, cell extracts, nonextractable residues) according to the work up procedure (Table 1). Clearly, cell cultures derived from 


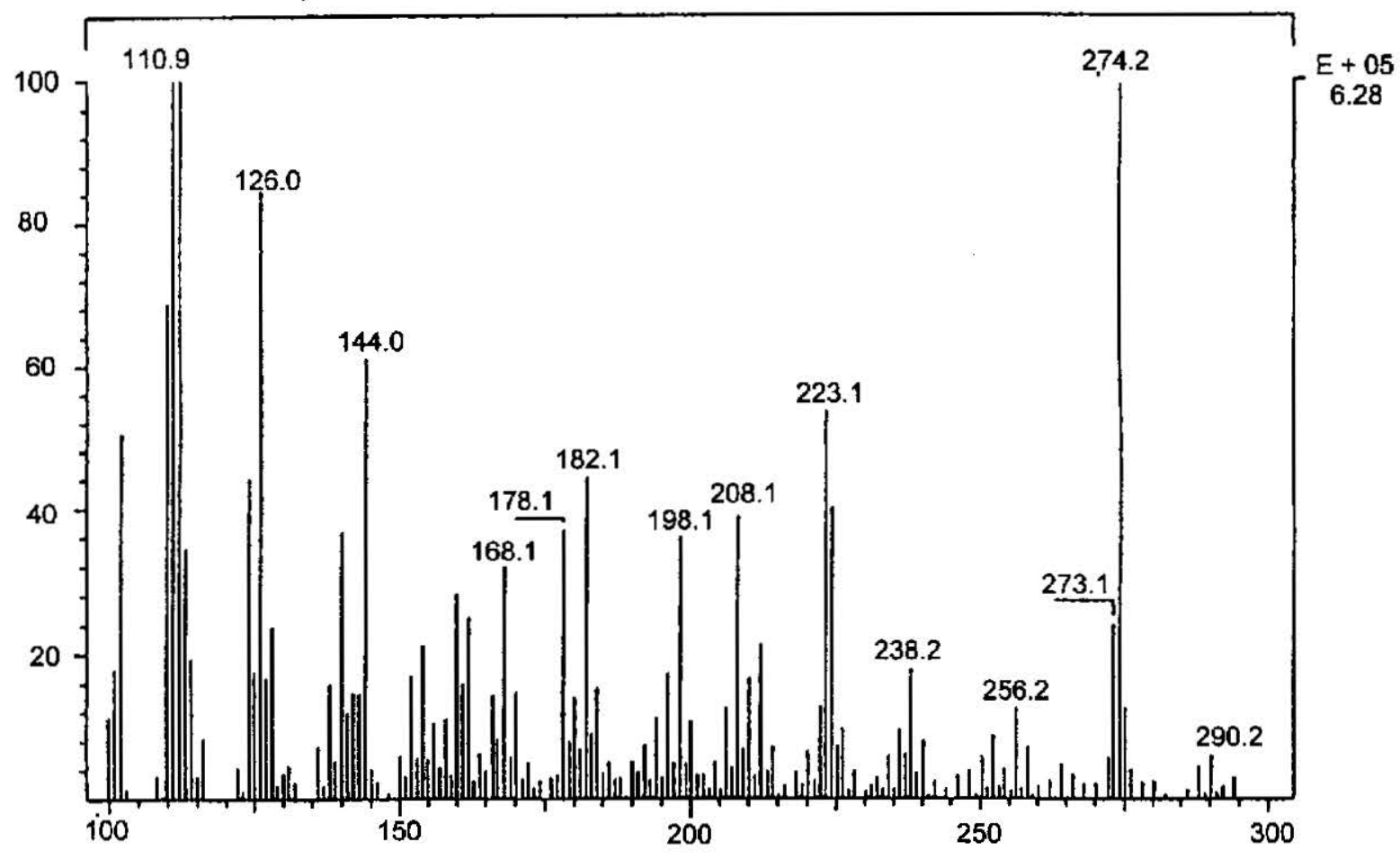

Figure 1.

Mass spectrum of the isolated $\beta$-D-glucoside of $\mathbf{M H}\left(\mathrm{m} / \mathrm{z}: 274[\mathrm{MH}]^{-}\right)$, fragments: $\mathrm{m} / \mathrm{z} 110.9 \mathrm{MH} ; 256,238,126$ fragments of the glucoside moiety).

monocot plant species could take up $\mathrm{MH}$ better $(>60 \%$ uptake in maize) than the dicot species (tobacco and soybean). A comparison of the metabolism rates (figures in parenthesis) revealed that $\mathrm{MH}$ was converted to a higher extent in the "dicot" cell cultures.

According to HPLC analysis, only $\mathrm{MH}$ could be detected in medium, whereas in methanolic extracts of the cells a second radiolabeled substance was present. This $\mathrm{MH}$ metabolite was identified as the $\beta$ - $\mathrm{D}$-glucoside of $\mathrm{MH}$ by co-chromatography with an authentic synthesized reference compound. After clean-up on SPE and MSanalysis with solid probe inlet (CI) in the negative mode of detection, we were able to clearly identify the underivatized $\mathrm{MH}-\mathrm{O}-\beta$-D-glucoside, both as a standard as well as isolated from tobacco (Figure 1).

Only in soybean but not in tobacco, maize or wheat, significant amounts of radioactivity (up to $18.3 \%$ ) were detected in the NER fraction.

Involvement of a glycosyltransferase in the conjugation of maleic bydrazide

The participation of a GT (EC 2.4.1-) in the conversion (Figure 2) of $\mathrm{MH}$ to its $O-\beta-\mathrm{D}$-glucoside conjugate was demonstrated by in vitro enzyme assays. Corresponding products were detected with HPLC-system I. As these analyses of the enzyme assays showed only one product peak, which co-chromatographed with the $\mathrm{MH}-\mathrm{O}-\beta-\mathrm{D}-$ glucoside reference compound, control experiments with 3,4-dichloroaniline (DCA), a well known xenobiotic substrate for $N$-glucosyltransferases ( $N$-GT), were performed with the in vitro enzyme assay in order to exclude the presence of a $N$-GT in the extract.

A comparison of specific O-GT activities (pkat/mg protein) for protein extracts originating from cell cultures or whole plants is depicted in Figure 3. In both systems, clearly tobacco had the highest O-GT activities, with $45 \pm 6 \mathrm{pkat} / \mathrm{mg}$ protein (cell culture) and 12,0 $\pm 1,7$ $\mathrm{pkat} / \mathrm{mg}$ protein (tobacco plants).

\section{Test of acid stability}

Treatment of the nonextractable residues from soybean under simulated stomach conditions $\left(0.1 \mathrm{M} \mathrm{HCl}, 37^{\circ} \mathrm{C}\right.$, $24 \mathrm{~h}$ ) released only $3 \%$ of the bound radioactivity. When dioxane $/ 0.1 \mathrm{M} \mathrm{HCl}(4: 1 \mathrm{v} / \mathrm{v})$ was employed, the release rate was $4.5 \%$. In both cases, one substance, correspon- 
<smiles>CC(CO)C1(O)C(O)C(O)C(Oc2ccc(=O)[nH]n2)OC1(C)CO</smiles>

Flgure 2

Tautomeric nature of MH and enzymatic conjugation of MH to its $\alpha-\beta$-D-glucoside.

ding to $80-90 \%$ of the released radioactivity, co-chromatographed with the authentic $\mathrm{MH}$ standard.

Simulated stomach conditions sufficed to cleave $\mathrm{MH}-\beta-\mathrm{D}$ glucoside completely within $24 \mathrm{~h}$. The cleavage proceeded rapidly for the first $10 \mathrm{~h}$ releasing $60 \%$ of the ${ }^{14} \mathrm{C}$ as free $\mathrm{MH}_{\mathrm{H}}$. The reaction was linear in this time period, whereas after $10 \mathrm{~h}$, the kinetics changed to a sigmoidallike progression of $\mathrm{MH}$-release. In contrast, a control incubation in distilled water revealed only 1-2\% cleavage after $24 \mathrm{~h}$.

\section{Fungal degradation and bioavailability studies}

The fungal degradation of free MH and its soya NER has been previously reported in detail (15). To summarize, mineralization of free $\mathrm{MH}$, judged as percent evolved ${ }^{14} \mathrm{CO}_{2}$, showed a quick release of ca $25 \%$ during the first three incubation days. This was followed by another $7 \%$ for the next three days. For the remainder of the incubation, a further $5 \%$ could be detected. The mineralization profile of the NER revealed a near linear production of $7 \%{ }^{14} \mathrm{CO}_{2}$ for the first six days, followed by a linear increase to $11 \%$ for the remaining 16 days.

Although the fungus was capable of solubilizing approximately $20 \%$ of the applied NER, based on released radioactivity into the medium, we could clearly show using PDA detection against authentic standards, that no free $\mathrm{MH}$ or $\mathrm{MH}$-glucoside was present at the end of the incubations. This was also the case after incubating free $\mathrm{MH}$ under the same conditions. Even the small percent of medium solubilized NER ( $3 \%)$ in the sterile controls

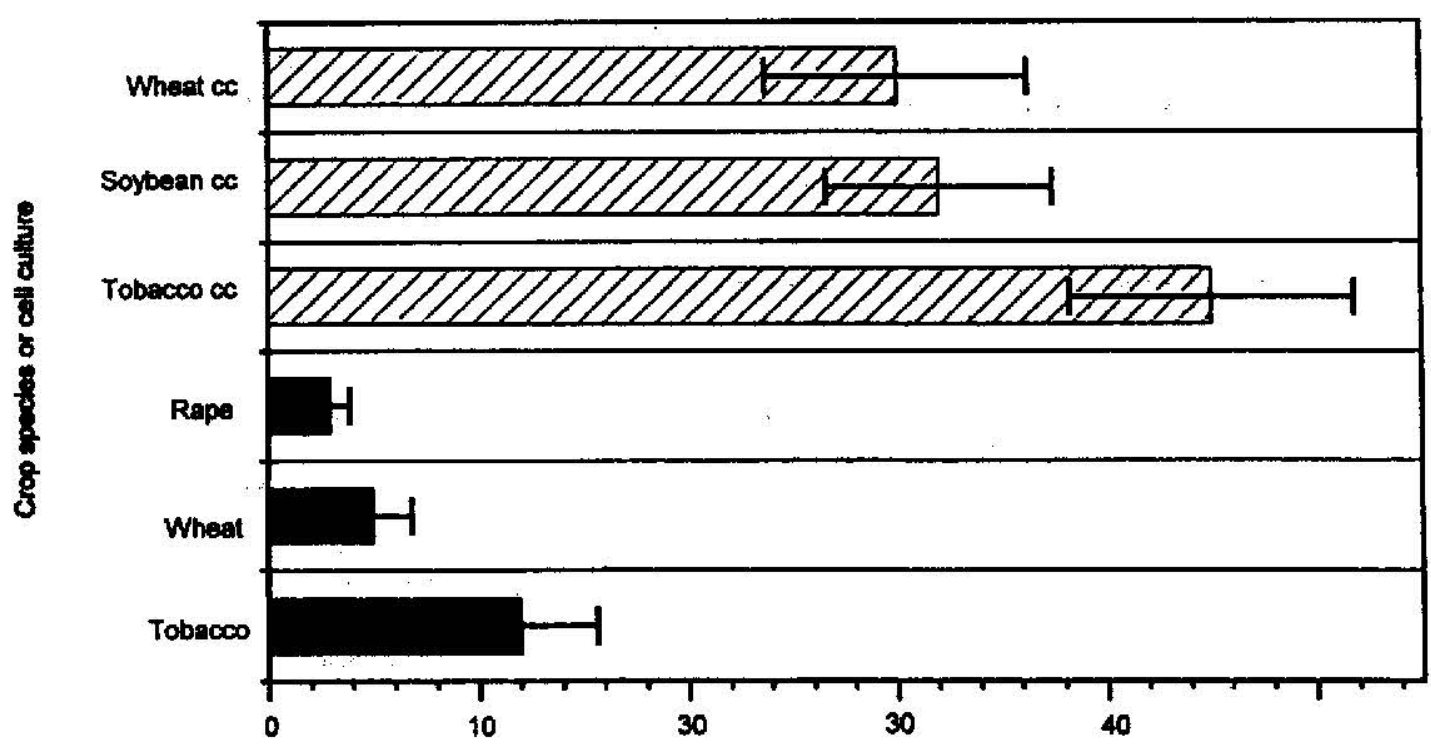

MH: O-Glycosyltranaferase activity (pkating protein)

Floure 3

Comparison of speclfic O-GT actlvities (pkat/mg proteln) in cell suspension cultures (cc) and whole plants given as average values of 5 replicates; error. bars indicate the standard deviations. 
showed no presence of these compounds. This may confirm true covalent bonding of $\mathrm{MH}$ into the NER fraction of soybean cells in cell cultures.

\section{DISCUSSION}

The present cell culture results confirm previous metabolic studies with intact tobacco plants (3) as well as with corn and pea seedlings (4). $\mathrm{MH}$ exhibited a relatively simple metabolic pattern giving rise mainly to the $\beta$-Dglucoside and to nonextractable residues. By performing the conversion of MH to its $\beta$-D-glucoside in vitro the participation of an O-GT (EC 2.4.1-) in this reaction could be demonstrated for the first time. No N-GT enzymatic activity towards $\mathrm{MH}$ or the standard test substrate DCA could be detected in protcin fractions showing the O-GT activity. It was proposed earlier that $\mathrm{MH}$ bound in plant food materials could be a serious human hazard (4). However, in tobacco as the representative culture for applying $\mathrm{MH}$, the nonextractable residue fraction was negligible. Even if there was a large amount of nonextractable residues, as in the case of soybean under simulated stomach conditions $(0.1 \mathrm{M} \mathrm{HCl}$, $37^{\circ} \mathrm{C}, 24 \mathrm{~h}$ ), the release rate of free $\mathrm{MH}$ was somewhat low $(3 \%)$. Whereas O-glucopyranosides, in general, possess relatively high acid stability (16), the $\beta$-D-glucoside of $\mathrm{MH}$ was completely hydrolysed even under mild simulated stomach conditions. This acid sensitivity can be partially explained because of an extraordinary structural feature of MH-O- $\beta$-D-glucoside which can isomerize back to its hydrazide tautomer (Figure 1). Acid lability of linkages of xenobiotics to plant polymers like lignin, cellulose or starch are prerequisites for toxicological effects (17).

The fungal ligninases, in combination with whole cultures, are well known for their ability to cleave and degrade a wide variety of artificial and native lignin macromolecules (18), often completely to $\mathrm{CO}_{2}$. Thus, the fungus may be used as a first natural indicator for the release and, hence, bioavailability, of any given xenobiotic covalently bound to a polymeric matrix. As we have previously shown (9), wheat NERs could be substantially mineralized by the fungus in nitrogenlimited medium. In no case, however, could the free starting monomeric xenobiotic be detected by HPLC analysis. This was also the case in this study, using the MH-NER of soybean. These observations are important considering that polymerization into a cell wall NER fraction may function as a detoxification process. The white rot fungus Phanerochate chrysosporium again proved to be an extremely potent degrader of polymer bound substances (15).

\section{REFERENCES}

1. Weed Science Society of America; in: Herbicide Handbook, 6th edition, Champaign, Illinois, 1989, pp 187-188.

2. Meyer, S.A., T.J. Sheets, and H.Seltmann: Maleic hydrazide residues in tobacco and their toxicological implications; in: Reviews of Environmental Contamination and Toxicology, edited by G.W. Ware, Springer, New York, 1987, pp. 43-60.

3. Frear, S.D., and H.R. Swanson: Behaviour and fate of $\left[{ }^{14} \mathrm{C}\right]$ maleic hydrazide in tobacco plants; J. Agric. Food Chem. 26 (1978) 660-665.

4. Nooden, L.D.: Metabolism and binding of ${ }^{14} \mathrm{C}$-maleic hydrazide; Plant Physiol. 45 (1970) 46-52.

5. Komoßa, D., I. Gennity and H. Sandermann, Jr.: Plant metabolism of herbicides with C-P bonds: Glyphosate; Pestic. Biochem. Physiol. 281 (1992) 85 94.

6. Newsome, W.A.: A method for the determination of maleic hydrazide and its B-D-glucoside in foods by high-pressure anion-exchange liquid chromatography: J. Agric. Food Chem. 28 (1980) 270-272.

7. Haas, M.: Metabolisierung von Xenobiotika durch pflanzliche Zellkulturen und Enzyme; Dissertation TU München-Weihenstephan 1997.

8. Kirk, T.K., E. Schultz, W. J. Connors, L.F Lorenz and J. G. Zeikus: Influence of culture parameters on lignin metabolism by Phanerochaete chrysosporium; Arch. Microbiol. 117 (1978) 277-285.

9. Arjmand, M. and H. Sandermann, Jr.: Mineralization of chloroaniline/lignin conjugates and of tree chloroanilines by the white rot fungus Phanerochaete chrysosporium; J. Agric. Food Chem. 33 (1985) 10551060.

10. Sandermann, H. Jr., D. Scheel and T. v.d. Trenck: Use of plant cell cultures to study the metabolism of environmental chemicals; Ecotoxicol. Environ. Saf. 8 (1984) 167-182.

11. Komoßa, D. and H. Sandermann, Jr.: Plant metabolic studies of the growth regulator maleic hydrazide; J. Agric. Food Chem. 43 (1995) 2713-2715.

12. Tien, M. and T.K. Kirk: Lignin-degrading enzyme from Phanerochate chrysosporium: purification, characterization and catalytic properties of a unique $\mathrm{H}_{2} \mathrm{O}_{2}$-requiring oxygenase; Proc. Natl. Acad. Sci. USA 81 (1984) 2280-2284.

13. Reddy, C.A.: The potential for white-rot fungi in the treatment of pollutants. Curr. Opin. Biotechnol. 6 (1995) 320-328.

14. Bradford, M. M.: A rapid and sensitive method for the quantification of microgram quantities of protein utilizing the principle of protein-dye binding; Anal. Biochem. 72 (1976) 248-254. 
15. May, R.G.; Sparrer, I.; Hoque, E.; Sandermann Jr., H.: Mineralization of native pesticidal plant cell wall metabolites by the white-rot fungus Phanerochaete chrysosporium; J. Agric. Food Chem. 45 (1997) 19111915.

16. Overend, W.G.: Glycosides; in: The Carbohydrates. Chemistry and Biochemistry, edited by W. Pigmann and D. Horton, Academic Press, New York, 1972, pp. 279-353.

17. Sandermann, H.Jr., T. J. Musick and P.W. Aschbacher: Animal bioavailability of a 3,4-dichloroaniline-lignin metabolite fraction from wheat; J. Agric. Food Chem. 40 (1992) 2001-2007.
18. Kirk, T.K. and R. L. Farrell: Enzymatic combustion: The microbial degradation of lignin; Ann. Rev. Microbiol. 41 (1987) 465-505.

Address for correspondence:

PD Dr. P. Schröder

GSF - Forschungszentrum für Umwelt

und Gesundheit $\mathrm{GmbH}$

Institut für Biochemische Pflanzenpathologie

Ingoldstädter Landstraße 1

D.85758 Oberschleißheim, F.R.G. 